\title{
Association study between genetic monoaminergic polymorphisms and OCD response to clomipramine treatment
}

\author{
Karen Miguita ${ }^{1,2}$, Quirino Cordeiro' ${ }^{1}$ Roseli Gedanke Shavitt ${ }^{1}$, \\ Eurípedes Constantino Miguel', Homero Vallada'
}

\begin{abstract}
In the present paper, we investigated the 5HTTLPR and STin2 polymorphisms in the promoter region of the serotonin transporter gene (SLC6A4), the G861C polymorphism (rs6296) of the serotonin receptor 1D beta (HTR1B), the T102C (rs6113) and C516T (rs6305) polymorphisms of the serotonin receptor gene subtype 2A (HTR2A), the DAT UTR, DAT intron 8 and DAT intron 14 of the dopamine transporter gene (SLC6A3), the Val-158-Met (rs4680) polymorphism of the COMT and the silent mutation G1287A (rs5569) in the norepinephrine transporter gene (SLC6A2). We genotyped 41 obsessive-compulsive disorder (OCD) outpatients, classified as good-responders $(n=27)$ and poor-responders $(n=14)$ to treatment with clomipramine according to the Yale Brown Obsessive-Compulsive Scale (YBOCS). Patients who achieved a reduction in symptoms of $40 \%$ or more in YBOCS after 14 weeks of treatment were considered good-responders. Genotypes and alleles distribution of the investigated polymorphisms were compared between both groups. We did not find association between the studied polymorphisms and clomipramine response in our sample.
\end{abstract}

Key words: $O C D$, clomipramine, serotonin receptor, serotonin transporter, dopamine transporter, norepinephrine transporter.

Estudo de associação entre polimorfismos genéticos monoaminérgicos e resposta à clomipramina no tratamento do TOC

\section{RESUMO}

No presente estudo, investigaram-se os polimorfismos 5HTTLPR e STin2 da região promotora do gene transportador de serotonina (SLC6A4), o G861C (rs6296) do receptor de serotonina 1D beta (HTR1B), os polimorfismos T102C (rs6113) e C516T (rs6305) do gene do receptor da serotonina subtipo 2A (HTR2A), os polimorfismos UTR, intron 8 e intron 14 do gene transportador de dopamina (SLC6A3), o Val-158-Met (rs4680) da COMT e a

Correspondence Homero Vallada

Rua Dr. Ovídio Pires de Campos 785 $1^{\circ}$ andar / sala 8 05403-010 São Paulo SP - Brasil E-mail: hvallada@usp.br

\section{Support}

This work was supported by grants from CAPES (\# 8817 K.M.) and FAPESP grants \# 99/01548-0 (R.G.S.) and \# 99/12205-7 (E.C.M. \& H.V). Dr. Miguel received speaker's honoraria from Solvay

Received 29 August 2010 Received in final form 17 November 2010 Accepted 24 November 2010 mutação G1287A (rs5569) do gene do transportador de norepinefrina (SLC6A2). Foram genotipados 41 pacientes com transtorno obsessivo-compulsivo (TOC), classificados como bons-respondedores $(n=27)$ e maus-respondedores $(n=14)$ ao tratamento com clomipramina, por meio do uso da Escala de Sintomas Obsessivos-Compulsivos Yale Brown (YBOCS). Foram considerados bons-respondedores os pacientes que tiveram redução nos sintomas em $40 \%$ ou mais na YBOCS, após 14 semanas de tratamento. A distribuição dos genótipos e alelos estudados foi comparada entre os dois grupos. Não foi encontrada associação entre estes polimorfismos investigados e a resposta à clomipramina na amostra estudada.

Palavras-chave: TOC, clomipramina, receptor serotonérgico, transportador de serotonina, transportador de dopamina, transportador de norepinefrina.

IInstitute and Department of Psychiatry, University of São Paulo Medical School, São Paulo SP, Brazil; ${ }^{2}$ Adolfo Lutz Institute, São Paulo SP, Brazil. 
Clinical and pharmacological data suggest the involvement of the serotoninergic system in the treatment of obsessive-compulsive disorder (OCD) patients due to the effect of serotonin reuptake inhibitors (SRIs), such as clomipramine. However, about $40-60 \%$ of the patients do not respond to the treatment using these drugs ${ }^{1}$. Treatment failure may occur not only because of the occasional lack of efficacy of SRIs but also due to a lack of medication compliance, adverse drug reactions, or drug interactions. Individual genetic differences may also play an important role in determining clinical responses to medications and/or the adverse side effects experienced.

Pharmacogenetic investigations in other psychiatric disorders have started to present some promising results. Despite of the complexity underlying the biological processes between psychiatric phenotypes and drug treatments, the identification of some genetic variants associated with drug response in psychosis have been reported ${ }^{2}$.

The present study is a pharmacogenetic investigation of OCD and clomipramine treatment response. We have previously investigated the effect of socio-demographic and clinical features on the short-term response to pharmacological treatment in 41 OCD patients ${ }^{3}$. Now, using the same data, we are looking at the distribution of some genetic variants between the good and poor responders to clomipramine.

The most important theory for explaining the biological basis of clomipramine action is their ability to improve monoaminergic transmission. Clomipramine acts in the transmission of different biogenic monoamine systems: serotonin, noradrenaline, and dopamine. Since this first theory, other explanations based on the ability of clomipramine to act on the abnormal function of monoamine receptors or some impaired signalling pathways have been suggested. Behavioural, electrophysiological, and microdialysis studies have shown that serotonin receptors, mainly 5-HT1A, 5-HT1B, and 5-HT2C subtypes, exert a key role in modulating clomipramine activity. Indirect activation of neurotransmitter receptors by clomipramine may also lead, via increases in endogenous levels of serotonin in synapses in specific brain regions to the activation of various $G$ protein-coupled receptors, signal transduction, transcription factors, and neurotrophic factors such as brain-derived neurotrophic factor ${ }^{4}$. As catechol-O-methyltransferase (COMT) is one of the enzymes that degrade catecholamines, such as dopamine and norepinephrine, polymorphisms that encode such protein may also influence clomipramine action.

Thus, the investigated polymorphisms were from the serotonergic, dopaminergic and noradrenergic systems. They were: the serotonin-transporter-linked polymorphic region (5HTTLPR) and STin2 variable number of tandem repeats (VNTR) polymorphisms in the promoter region of the serotonin transporter gene (SLC6A4), the G861C polymorphism (rs6296) of the serotonin receptor 1D beta gene (HTR1B), the T102C (rs6113) and C516T (rs6305) polymorphisms of the serotonin receptor subtype 2A gene (HTR2A), the VNTR untranslated region (UTR), VNTR intron 8 and intron 14 of the dopamine transporter gene (SLC6A3), the Val-158-Met (rs4680) polymorphism of the COMT gene (COMT) and the silent mutation G1287A (rs5569) in the norepinephrine transporter gene (SLC6A2).

\section{METHOD}

\section{Study sample}

Our sample consisted of 41 (male $=23$; female $=18)$ OCD outpatients, recruited by psychiatrists from the Psychiatric Institute, University of São Paulo Medical School in Brazil. All patients were diagnosed with OCD according to DSM-IV criteria ${ }^{5}$ and were treated with clomipramine, a tryciclic antidepressant and a SRI, for 14 weeks [mean dose of $235.5( \pm 40.8) \mathrm{mg} /$ day]. The response to the drug was a reduction of $40 \%$ or more in the Yale Brown Obsessive-Compulsive Scale (Y-BOCS) total score. After 14 weeks, 27 patients were considered good responders and 14 were considered poor responders to clomipramine. Further details can be found in Shavitt et al. ${ }^{3}$.

All patients provided written informed consent to participate in the study, including permission for blood collection for DNA analysis.

\section{Genotyping}

Genomic DNA was extracted directly from peripheral blood using Salting out protocol.

\section{Investigated polymorphisms}

5-HTTLPR - The insertion/deletion polymorphism of 44bp (variants l e s) in the promoter region of the serotonin transporter gene (SLC6A4) was analyzed using primers and PCR conditions previously described by Heils et al. ${ }^{6}$. After amplification the fragments $(l=528 \mathrm{bp}$ and $s=484 \mathrm{bp}$ ) were separated by electrophoresis in $2 \%$ agarose gel and visualized under UV light.

Stin2 - A VNTR located in intron 2 of the SLC6A4 gene was analyzed according to the conditions described by McKenzie and Quinn ${ }^{7}$. This VNTR has 9, 10 or 12 repetitions of a fragment with approximated $17 \mathrm{bp}$. After amplification the fragments $(9=250 \mathrm{pb}, 10=267 \mathrm{pb}$ and $12=300 \mathrm{pb}$ ) were separated by electrophoresis in agarose gel and visualized under UV light.

HTR1B (G861C) - 5HT1DBeta genotype was determined as a restriction fragment length polymorphism (RFLP) after PCR amplification and digested with Hinc II according to the method of Mundo et al. ${ }^{8}$. After amplification, the fragments (142bp, 310bp and 452bp) were 
separated by electrophoresis in $2 \%$ agarose gel and visualized under UV light.

HTR2A (T102C) - Genotyping of the T102C polymorphism of the HTR2A receptor gene was done using primers and conditions described by Warren et al. ${ }^{9}$. After amplification, PCR products were digested with MspI and separated by electrophoresis in agarose gel and visualised under UV light. The fragments sizes were one single band of $342 \mathrm{bp}$ for the allele $102 \mathrm{~T}$ and two bands of $216 \mathrm{bp}$ and $126 \mathrm{bp}$ for the allele $102 \mathrm{C}$.

HTR2A (C516T) - The primers and PCR conditions for the analysis of the C516T polymorphism of the HTR2A receptor gene were described by was Arranz et al. ${ }^{10}$. The fragments were digested with Sau 96I enzyme and separated by electrophoresis in agarose gel.

DAT UTR - A 40 bp VNTR polymorphism in of the dopamine transporter gene (SLC6A3) was investigated. Polymerase chain reaction (PCR) was carried out using primers and conditions described by Vandengergh et al. ${ }^{11}$. After amplification the genotypes were determined by electrophoresis in $2 \%$ agarose gels stained with ethidium bromide.

DAT intron 8 - A 30 bp VNTR polymorphism in of the SLC6A3 gene was investigated. Polymerase chain reaction (PCR) was carried out using primers and conditions described by Guindalini et al. ${ }^{12}$. After amplification the genotypes were determined by electrophoresis in agarose gels stained with ethidium bromide.

DAT intron 14 - Genotyping of the polymorphism located in intron 14 of the SLC6A3 gene was done using primers and PCR conditions described by Greenwood and $\mathrm{Kelsoe}^{13}$. After amplification the genotypes were determined by electrophoresis in agarose gels stained with ethidium bromide and viewed under UV light.

COMT (Val-158-Met) - The Val-158-Met polymorphism of the cathecol-o-methiltransferase (COMT) gene was analyzed according to conditions described previously by Daniels et al. ${ }^{14}$. The fragments were digested with NlaIII enzyme and separated by electrophoresis in a $4 \%$ agarose gel.

NET (1287A/G) - The exonic silent polymorphism (1287 A/G) of the noradrenaline transporter gene (NET) was analyzed with primers and conditions described by Jönsson et al. ${ }^{15}$. PCR products were resolved on $2 \%$ agarose gels and visualized by ultra-violate light after ethidium bromide staining.

To avoid errors, the genotyping was read by two independently trained research technicians. When a disagreement arose the genotyping was repeated.

\section{Statistical analysis}

Allelic and genotypic distributions of the polymorphisms studied were compared between good responders
Table 1. Demographic and clinical characteristics of the sample.

\begin{tabular}{|c|c|c|c|}
\hline \multicolumn{2}{|c|}{ Variables } & \multirow{2}{*}{$\begin{array}{c}\text { Total } \\
22\end{array}$} & \multirow{2}{*}{$\begin{array}{c}\text { Percentage (\%) } \\
53.7\end{array}$} \\
\hline Age & $20-30$ & & \\
\hline & $31-40$ & 13 & 31.7 \\
\hline & $>41$ & 6 & 14.6 \\
\hline \multirow[t]{2}{*}{ Sex } & Male & 23 & 56.1 \\
\hline & Female & 18 & 43.9 \\
\hline \multicolumn{2}{|c|}{$\begin{array}{l}\text { Good-responders ( } \geq 40 \% \\
\text { reduction in YBOCS scores) }\end{array}$} & 27 & 65.8 \\
\hline \multicolumn{2}{|c|}{$\begin{array}{l}\text { Poor-responders ( }<40 \% \\
\text { reduction in YBOCS scores) }\end{array}$} & 14 & 34.2 \\
\hline \multicolumn{2}{|l|}{ Total } & 41 & 100 \\
\hline
\end{tabular}

and poor responders groups using Clump v1.9. p-values smaller than 0.05 were considered to be significant. A test for deviations from the Hardy-Weinberg equilibrium was performed using the HWE program. For all statistic tests the level of significance adopted was $\alpha<0.05$, or $5 \%$. All groups were in Hardy-Weinberg equilibrium for the polymorphism investigated.

\section{RESULTS}

Demographic variables are presented in Table 1.

No significant difference was observed in the genotype or allele distribution for good and poor responders to clomipramine for any of the studied gene variants (Tables 2, 3 and 4).

\section{DISCUSSION}

In the present study ten genetic variants described above were genotyped in 41 OCD patients, and the distribution of those variants were compared between the groups of good-responders $(n=27)$ and of the poor-responders $(n=14)$ to clomipramine. This is one of the few studies of pharmacogenetics involving OCD phenotype despite of the negative results, i.e. no statistical significant differences between the distribution of those variants and the two groups were found.

The other pharmacogenetic studies investigating the 5HTTLPR polymorphism of the SLC6A4 gene in OCD patients taking fluoxetine or clomipramine did not find any significant difference between the groups of good and poor responders ${ }^{16,17}$. In 1998, McDougle et al. ${ }^{18}$ found in a sample of 33 OCD patients a higher frequency of the L-allele (but not statistically significant) in the poorer response group to SRIs (clomipramine, fluvoxamine, fluoxetine, sertraline and paroxetine). Also in 1998, Cavallini et al. ${ }^{19}$ with the Cys23Ser polymorphism of the HTR2C gene found no association between this polymorphism and therapeutic response to clomipramine. In a more recent 
Table 2. Allele frequencies and genotype distribution of the serotonergic gene loci.

\begin{tabular}{|c|c|c|c|c|c|c|c|c|c|c|}
\hline \multirow[b]{2}{*}{$5 H T T L P R$} & \multirow[t]{2}{*}{$\mathrm{n}$} & \multirow{2}{*}{\multicolumn{2}{|c|}{$\begin{array}{c}\text { Alleles } \\
\mathrm{S}\end{array}$}} & & \multirow[t]{2}{*}{$p$} & \multicolumn{4}{|c|}{ Genotypes } & \multirow[t]{2}{*}{$p$} \\
\hline & & & & & & $\mathrm{LL}$ & LS & SS & & \\
\hline Good-responders & 27 & $30(55.6 \%)$ & $24(44.4 \%)$ & & 0.27 & $7(25.9 \%)$ & $16(59.3 \%)$ & $4(14.8 \%)$ & & 0.54 \\
\hline Poor-responders & 14 & 12 (42.9\%) & $16(57.1 \%)$ & & & $3(21.4 \%)$ & $6(42.9 \%)$ & $5(35.7 \%)$ & & \\
\hline STin 2 & & 9 & 10 & 12 & & $9-12$ & $10-10$ & $10-12$ & $12-12$ & \\
\hline Good-responders & 27 & - & 20 (37.0\%) & $34(63.0 \%)$ & 0.36 & - & $5(18.5 \%)$ & $10(37.0 \%)$ & $12(44.5 \%)$ & 0.35 \\
\hline Poor-responders & 14 & $1(3.6 \%)$ & $9(32.1 \%)$ & $18(64.3 \%)$ & & $1(7.1 \%)$ & $1(7.1 \%)$ & $7(50.0 \%)$ & $5(35.8 \%)$ & \\
\hline HTR1B & & G & $C$ & & & GG & $\mathrm{GC}$ & $\mathrm{CC}$ & & \\
\hline Good-responders & 27 & $42(77.8 \%)$ & $12(22.2 \%)$ & & 0.33 & $16(59.3 \%)$ & $10(37.0 \%)$ & $1(3.7 \%)$ & & 0.82 \\
\hline Poor-responders & 14 & $19(67.9 \%)$ & $9(32.1 \%)$ & & & $6(42.9 \%)$ & $7(50.0 \%)$ & $1(7 . \%)$ & & \\
\hline HTR2A (T102C) & & $T$ & C & & & $\Pi$ & $\mathrm{TC}$ & $\mathrm{CC}$ & & \\
\hline Good-responders & 27 & $12(22.2 \%)$ & $42(77.8 \%)$ & & 0.33 & - & $12(44.4 \%)$ & 15 (55.6\%) & & 0.9 \\
\hline Poor-responders & 14 & $9(32.1 \%)$ & $19(67.9 \%)$ & & & $1(7.1 \%)$ & $7(50.0 \%)$ & $6(42.9 \%)$ & & \\
\hline HTR2A (C516T) & & 1 & 2 & & & 12 & 22 & & & \\
\hline Good-responders & 27 & $11(20.4 \%)$ & $43(79.6 \%)$ & & 0.4 & $11(10.7 \%)$ & $16(59.3 \%)$ & & & 0.32 \\
\hline Poor-responders & 14 & $8(28.6 \%)$ & $20(71.6 \%)$ & & & $8(57.1 \%)$ & $6(42.9 \%)$ & & & \\
\hline
\end{tabular}

Table 3. Allele frequencies and genotype distribution of the polymorphisms of the dopamine transporter gene (DAT).

\begin{tabular}{|c|c|c|c|c|c|c|c|c|c|c|c|c|}
\hline & $\mathrm{N}$ & & Allel & & & $p$ & & & jenotypes & & & $p$ \\
\hline DAT UTR & & 8 & 9 & 10 & 11 & & $9-9$ & $10-8$ & $10-9$ & $10-10$ & $11-10$ & \\
\hline Good-responders & 27 & $1(1.9 \%)$ & $18(33.3 \%)$ & $33(61.1 \%)$ & $2(3.7 \%)$ & 0.51 & $3(11.1 \%)$ & $4(3.7 \%)$ & $12(44.5 \%)$ & $9(33.3 \%)$ & $2(7.4 \%)$ & 0.35 \\
\hline Poor-responders & 14 & - & $14(50.0 \%)$ & $14(50.0 \%)$ & - & & $4(28.6 \%)$ & - & $6(42.8 \%)$ & $4(28.6 \%)$ & - & \\
\hline DAT INTRON 8 & & 2 & 3 & & & & $2-2$ & $2-3$ & $3-3$ & & & \\
\hline Good-responders & 27 & $19(35.2 \%)$ & $35(64.8 \%)$ & & & 0.78 & $3(11.1 \%)$ & $13(48.2 \%)$ & $11(40.7 \%)$ & & & 0.96 \\
\hline Poor-responders & 14 & $9(32.1 \%)$ & 19 (67.9\%) & & & & $1(7.1 \%)$ & $7(50.0 \%)$ & $6(42.9 \%)$ & & & \\
\hline DAT INTRON 14 & & S & L & & & & SS & SL & $\mathrm{LL}$ & & & \\
\hline Good-responders & 27 & 19 (35.2\%) & $35(64.8 \%)$ & & & 0.95 & $21(77.8 \%)$ & $5(18.5 \%)$ & $1(3.7 \%)$ & & & 0.92 \\
\hline Poor-responders & 14 & $9(32.1 \%)$ & $19(67.9 \%)$ & & & & $11(78.6 \%)$ & $3(21.4 \%)$ & - & & & \\
\hline
\end{tabular}

Table 4. Allele frequencies and genotype distribution of the polymorphisms of the cathecolomethyltransferase (COMT) and norephinetrine transporter genes.

\begin{tabular}{lcccccccc}
\hline & $\mathbf{n}$ & \multicolumn{2}{c}{ Alleles } & $\mathrm{p}$ & & Genotypes & $\mathrm{p}$ \\
\hline COMT & & $\mathrm{H}$ & $\mathrm{L}$ & & $\mathrm{HH}$ & $\mathrm{HL}$ & $\mathrm{LL}$ & \\
Good-responders & 27 & $30(55.6 \%)$ & $24(44.4 \%)$ & 0.45 & $7(25.9 \%)$ & $16(59.3 \%)$ & $4(14.8 \%)$ & 0.34 \\
Poor-responders & 14 & $18(64.3 \%)$ & $10(35.7 \%)$ & & $7(50.0 \%)$ & $4(28.6 \%)$ & $3(21.4 \%)$ & \\
NET & & $\mathrm{G}$ & $\mathrm{A}$ & & $\mathrm{GG}$ & $\mathrm{AG}$ & $\mathrm{AA}$ & \\
Good-responders & 27 & $37(68.5 \%)$ & $17(31.5 \%)$ & 0.54 & $12(44.4 \%)$ & $13(48.2 \%)$ & $2(7.4 \%)$ & 0.76 \\
Poor-responders & 14 & $21(75.0 \%)$ & $7(25.0 \%)$ & & $8(57.2 \%)$ & $5(35.7 \%)$ & $1(7.1 \%)$ & \\
\hline
\end{tabular}


study, Denys et al. ${ }^{20}$ observed that in the paroxetine treated patients, the majority of responders were homozygotic to allele $\mathrm{G}$ of the $1438 \mathrm{G} / \mathrm{A}$ polymorphism of the HTR2A gene. It was also observed that the majority of the patients who responded to treatment with venlafaxine carried the S/L genotype of the 5-HTTLPR polymorphism.

The results of our investigation are in accordance with most of the published reports, since no statistically significant differences were observed either for the genotype or for the allelic distributions in our sample. However, an important methodological limitation leading to negative results in our and previous studies may be the sample size. Most of the studies involving one specific drug had only a few dozen participant patients. Another possible confounding factor could be population stratification, especially when the studied sample has a highly admixed ethnicity, such as in Brazil ${ }^{21}$. In addition, physical characteristics are not adequate predictors of genomic ancestry in the Brazilian population, which therefore render the ethnical matching in casecontrols studies difficult ${ }^{22}$. Phenotype criteria used for the analysis may not reflect a correct division of good and poor responders, due to the arbitrary selection of the threshold or due to the relatively short follow-up period of the drug response results. Finally, another limitation of the present study is related to the absence of metabolising genetic polymorphisms investigation. Drug-metabolising enzymes have been identified as a major source of pharmacokinetic variability within and between patients. Much focus has been given to genetic-based differences in the activity of certain cytochrome (CYP) P450 enzymes responsible for the metabolism of a wide variety of commonly used drugs, including clomipramine. Genetic polymorphisms coding for these enzymes can influence their ability to metabolise such drug. The P450 enzymes have been classified according to their amino-acid homology: CYP1A, CYP2A6, CYP2B6, CYP2C, CYP2D6, CYP2E1, and CYP3A enzymes account for approximately $70 \%$ of human liver CYP. In order of the large number of patients necessary, only few studies with limited power directly assessing the question of possible association between these polymorphisms and antidepressant response are available ${ }^{23}$. They indicate more predictive power for the avoidance of adverse drug reactions rather than clinical efficacy. However, no study analysing the possible influence of CYP450 polymorphisms on OCD response to clomipramine treatment is yet available.

In conclusion, this study investigated 10 genetic variants from six loci in OCD patients with good and poor response to clomipramine. In order to confirm the results, a replication in larger and independent samples is mandatory and/or the performance of future meta-analysis of published data on this subject.
ACKNOWLEDGMENTS - We would like to thank the contribution of Elisabete Miracca and Sara Campos for the lab work results.

\section{REFERENCES}

1. Pigott TA, Seay SM. A review of the efficacy of selective serotonin reuptake inhibitors in obsessive-compulsive disorder. J Clin Psychiatry 1999;60:101-106. 2. de Leon J, Arranz MJ, Ruaño G. Pharmacogenetic testing in psychiatry: a review of features and clinical realities. Clin Lab Med 2008:28:599-617.

3. Shavitt RG, Belotto C, Curi M, et al. Clinical features associated with treatment response in obsessive-compulsive disorder. Compr Psychiatry 2006; 47:276-281

4. Stahl SM, Grady MM. Differences in mechanism of action between current and future antidepressants. J Clin Psychiatry 2003;64:137.

5. American Psychiatric Association. Diagnostic and statistical manual of mental disorders. $4^{\text {th }}$ edition. Washington, DC: American Psychiatric Association, 1994.

6. Heils A, Teufel A, Petri S, et al. Allelic variation of human serotonin transporter gene expression. J Neurochem 1996;66:2621-2624.

7. MacKenzie A, Quinn J. A serotonin transporter gene intron 2 polymorphic region, correlated with affective disorders, has allele-dependent differential enhancer-like properties in the mouse embryo. Proc Natl Acad Sci U S A 1999;96:15251-15255.

8. Mundo E, Richter MA, Sam F, Macciardi F, Kennedy JL. Is the 5-HT(1Dbeta) receptor gene implicated in the pathogenesis of obsessive-compulsive disorder? Am J Psychiatry 2000;157:1160-1161.

9. Warren JT Jr, Peacock ML, Rodriguez LC, Fink JK. An Mspl polymorphism in the hyman serotonin receptor gene (HTR2): detection by DGGE and RFLP analysis. Hum Mol Genet 1993;2:338.

10. Arranz $M$, Collier $D$, Sodhi $M$, et al. Association between clozapine response and allelic variation in 5-HT2A receptor gene. Lancet 1995;346:281-282.

11. Vandenbergh DJ, Persico AM, Hawkins AL, et al. Human dopamine transporter gene (DAT1) maps to chromosome 5 p15.3 and displays a VNTR. Genomics 1992;14:1104-1106.

12. Guindalini $C$, Howard M, Haddley $K$, et al. A dopamine transporter gene functional variant associated with cocaine abuse in a Brazilian sample. Proc Natl Acad Sci U S A 2006;103:4552-4557.

13. Greenwood TA, Kelsoe JR. Promoter and intronic variants affect the transcriptional regulation of the human dopamine transporter gene. Genomics 2003:82:511-520.

14. Daniels JK, Williams NM, Williams J, et al. No evidence for allelic association between schizophrenia and a polymorphism determining high or low catechol O-methyltransferase activity. Am J Psychiatry 1996;153:268-270.

15. Jönsson EG, Nothen MM, Gustavsson JP, et al. Polymorphisms in the dopamine, serotonin, and norepinephrine transporter genes and their relationships to monoamine metabolite concentrations in CSF of healthy volunteers. Psychiatry Res 1998;79:1-9.

16. Billett EA, Richter MA, King N, Heils A, Lesch KP, Kennedy JL. Obsessive compulsive disorder, response to serotonin reuptake inhibitors and the serotonin transporter gene. Mol Psychiatry 1997;2:403-406.

17. Di Bella D, Erzegovesi S, Cavallini MC, Bellodi L. Obsessive-compulsive disorder, 5-HTTLPR polymorphism and treatment response. Pharmacogenomics J 2002;2:176-181

18. McDougle CJ, Epperson CN, Price LH, Gelernter J. Evidence for linkage disequilibrium between serotonin transporter protein gene (SLC6A4) and obsessive compulsive disorder. Mol Psychiatry 1998;3:270-273.

19. Cavallini MC, Di Bella D, Pasquale L, Henin M, Bellodi L. 5HT2C CYS23 polymorphism is not associated with obsessive-compulsive disorder. Psychiatry Res 1998;77:97-104.

20. Denys D, Van Nieuwerburgh F, Deforce D, Westenberg HG. Prediction of response to paroxetine and venlafaxine by serotonin-related genes in obsessive-compulsive disorder in a randomized, double-blind trial. J Clin Psychiatry 2007;68:747-753.

21. Silva MA, Cordeiro Q, Miracca EC, Guindalini C, Vallada H. Distribution of alleles of the VNTR polymorphism in the 3'-untranslated region of the DAT1 gene (SLC6A3) in São Paulo/Brazil and its importance to genetic studies of neuropsychiatric disorders in ethically admixed populations. Rev Med Chil 2005;133:1392-1393

22. Cordeiro Q, Souza BR, Correa H, et al. A review of psychiatric genetics research in the Brazilian population. Rev Bras Psiquiatr 2009;31:154-162.

23. Spina E, Gitto C, Avenoso A, Campo GM, Caputi AP, Perucca E. Relationship between plasma desipramine levels, CYP2D6 phenotype and clinical response to desipramine: a prospective study. Eur J Clin Pharmaco 1997;51:395-398. 